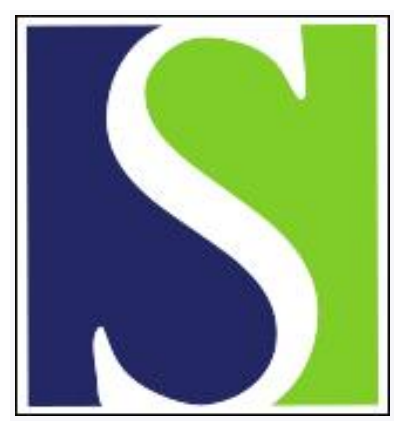

Scand J Work Environ Health 1997;23(3):199-205

https://doi.org/10.5271/sjweh.199

Issue date: Jun 1997

Urinary 1-naphthol excretion in the assessment of exposure to creosote in an impregnation facility

by Heikkilä PR, Luotamo M, Riihimäki V

Key terms: ambient monitoring; biological monitoring; polycyclic aromatic hydrocarbon; skin absorption; wood impregnation

This article in PubMed: www.ncbi.nlm.nih.gov/pubmed/9243730

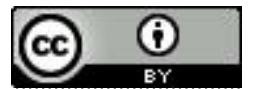




\title{
Urinary 1-naphthol excretion in the assessment of exposure to creosote in an impregnation facility
}

\author{
by Pirjo R Heikkilä, PhL, ${ }^{1}$ Marita Luotamo, PhD, ${ }^{2}$ Vesa Riihimäki, $M D^{3}$
}

\begin{abstract}
Heikkilä PR, Luotamo M, Riihimäki V. Urinary 1-naphthol excretion in the assessment of exposure to creosote in an impregnation facility. Scand J Work Environ Health 1997;23(3):199-205.
\end{abstract}

\begin{abstract}
Objectives This study explored the possibility of using urinary 1-naphthol excretion as a marker of complex exposure among workers handling creosote.

Methods Urine specimens of 6 workers from a creosote impregnation plant, where railroad ties were impregnated with coal tar creosote, were collected during 1 workweek, and the concentration of 1-naphthol was determined. 1-Naphthol in spot urine samples of 5 occupationally nonexposed male smokers was used as the background reference. Concurrently, naphthalene and 10 different polycyclic aromatic hydrocarbons (PAH) were determined in personal air samples.

Results The mean airborne exposure of the workers was $1.5 \mathrm{mg} / \mathrm{m}^{3}$ for vaporous naphthalene, $5.9 \mu \mathrm{g} / \mathrm{m}^{3}$ for particulate PAH and $1.4 \mu \mathrm{g} / \mathrm{m}^{3}$ for PAH with $4-6$ aromatic rings. The mean urinary concentration of 1 -naphthol at the end of the workshift was 20.5 (range $3.5-62.1$ ) $\mu \mathrm{mol} / \mathrm{l}$, whereas the referents' urinary concentration was below the detection limit $(0.07 \mu \mathrm{mol} / \mathrm{l})$. Airborne naphthalene correlated fairly well with 1 -naphthol when measured at the end of the shift $(\mathrm{r}=0.745)$.

Conclusions This method of analysis for 1-naphthol is sufficiently sensitive for measuring low occupational exposures to naphthalene. Low background exposures are, however, unlikely to result in detectable urinary levels of 1 -naphthol. Since naphthalene is the most abundant compound in creosote vapor, urinary 1-naphthol determination serves well as a biological marker of exposure to vaporous creosote. Urinary 1-naphthol alone is not, however, a suitable marker for inhalatory or cutaneous exposure to PAH originating from creosote.
\end{abstract}

Key terms ambient monitoring, biological monitoring, polycyclic aromatic hydrocarbons, skin absorption, wood impregnation.

Creosote, a blend of coal-tar distillation fractions, is widely used as a wood preservative. It contains hundreds of compounds, of which about 100 have been identified and quantified (1). It has about 20 major constituents with concentrations of more than $1 \%$ each (amounting to about $80 \%$ of the total) (2). Creosote can cause skin irritation and photosensitization, and the International Agency for Research on Cancer has determined that there is sufficient evidence for the carcinogenicity of creosote to animals but limited evidence to humans (3). A recent study showed an increased risk of skin cancer among creosote-exposed workers (4). The highest boiling fractions were shown to contain mutagenic compounds (2). DNA (deoxyribonucleic acid) adducts of polycyclic aromatic hydrocarbons (PAH) have been detected in the skin and lungs of mice after topical application of creosote to the skin of experimental animals (5).

Naphthalene is the most abundant component of creosote vapor (6), and it constitutes $10-16$ weight-\% of creosote oils (2). Naphthalene is a major airborne impurity also in occupational exposures related to the processing or handling of products with a coal tar and mineral oil base $(7,8,9,10)$, and even in cooking fumes (11). Naphthalene is used as an intermediate in the chemical and plastics industry, and in the manufacture of insecticides and fungicides. A common type of household mothball contains naphthalene.

Naphthalene is hydroxylated to a transitory epoxide metabolite which is rearranged to more stable naphthols and dihydrodiols $(12,13)$. Approximately $81-84 \%$ of

1 Uusimaa Regional Institute of Occupational Health, Helsinki, Finland.

2 Finnish Institute of Occupational Health, Biomonitoring Laboratory, Helsinki, Finland.

3 Finnish Institute of Occupational Health, Unit of Toxicological Risk Assessment, Helsinki, Finland.

Reprint requests to: Ms Pirjo R Heikkilä, Uusimaa Regional Institute of Occupational Health, Arinatie 3, FIN-00370 Helsinki, Finland. 
orally administered naphthalene was excreted in the urine of rats mainly as metabolites, being $4.6 \%$ of the dose recovered as 1 -naphthol and its glucuronide (14). Urinary 1-naphthol was found to indicate naphthalene exposure in swine after oral administration (15). In an in vitro study, human liver microsomes metabolized naphthalene to 1,2-dihydrodiol and 1-naphthol. The former accounted for $80 \%$ of the metabolism (16).

The aim of this study was to explore to what extent we could assess creosote workers' exposure by using urinary 1-naphthol excretion as a marker of the complex exposure. We measured the concentrations of naphthalene and $10 \mathrm{PAH}$ in personal air samples during a workweek and concurrently monitored the urinary levels of 1naphthol and 1-pyrenol on 3 workdays. The results concerning 1-pyrenol in urine have been published separately (17).

\section{Subjects and methods}

\section{Subjects and study design}

The study was carried out in a creosote impregnation plant where railroad ties were impregnated with Polish creosote. The creosote oil contained 10 weight-\% naphthalene and the 3-6 aromatic ring containing PAH amounted to 9 weight-\% (2). The wooden railroad ties were impregnated in a pressure cylinder; the treated material was transported across the yard to a sheltered area where metal plates were screwed to the tie for fixing the rails. Six men (the impregnator, 2 assistant operators, the truck driver and 2 tie platers) participated in this study. All the workers used protective leather gloves and cotton overalls, and no one used a respirator. The workers followed the normal 8 -h daytime shifts with the exception that 2 employees (an assistant operator and the truck driver) worked 4 h of overtime (until 1800) on Monday.

Urine specimens were collected during 1 workweek concurrently with the airborne naphthalene and $\mathrm{PAH}$ sample collection. Urine specimens were collected on 3 days (on Monday, Wednesday and Friday) in the morning before the start of the workshift $(0500-0700)$, during the lunch hour (1000-1330), after the workshift (1400-1530), in the evening (1900-2300), and the next morning ( $0500-0700)$. The workers were asked to collect all the urine during the weekend from Saturday morning until Monday morning, and 1 sample was collected after the summer holiday. However, for some participants, it was not possible to collect all the samples. Urine was passed into polyethylene bottles $(500 \mathrm{ml})$, which were subsequently stored in a freezer at $-20^{\circ} \mathrm{C}$.

Assistant operator 1, the truck driver and tie plater 1 did not smoke, whereas the other 3 workers smoked from 10 to 30 cigarettes a day. Five male smoking refer- ents were asked to give spot urine samples for comparison.

\section{Air sampling and analysis}

Airborne naphthalene samples were collected on XAD-2 resin (1 226-90-66) at a flow rate of $0.2 \mathrm{ml} / \mathrm{min}$ in the breathing zone of the workers. The time-weighted average concentrations in the morning (from about 0630 to 1100 ) and in the afternoon (from about 1130 to 1500 ) were measured over a workweek. After the sampling the tubes were sealed immediately and stored at $+3 \% \mathrm{C}$. The samples were analyzed within 4 weeks. Naphthalene was desorbed from XAD-2 with carbon disulfide $(5 \mathrm{ml})$ in an ultrasonic bath for $30 \mathrm{~min}$. The gas chromatographic analyses were performed with a Hewlett Packard gas chromatograph 5890 using a flame ionization detector. The temperature of the capillary column $(25 \mathrm{~m} \times 0.3$ $\mathrm{mm}, \mathrm{SE}-54$ ) was programmed to proceed from $60^{\circ} \mathrm{C}$ to $200^{\circ} \mathrm{C}$ at $15^{\circ} \mathrm{C} / \mathrm{min}$. The within-run variation of the analysis was $6^{\circ}(\mathrm{N}=10)$. The recovery from the XAD-2 resin was $85(\mathrm{SD} 9) \%(\mathrm{~N}=5)$.

Particulate PAH were measured in parallel with the XAD-2 vapor samples. They were collected onto the prewashed glass fiber filters and analyzed with reversed phase high-pressure liquid chromatography and fluorescence detection (Perkin Elmer LS4) (17). The total concentration of PAH was the sum of the concentration of 10 particulate $\mathrm{PAH}$.

\section{1-Naphthol analysis}

The urinary 1-naphthol concentrations were analyzed by gas chromatography using an electron capture detector as a pentafluorobenzylbromide derivative, a modification of the method by Keimig \& Morgan (15). The basic principle of the method was to hydrolyze urinary 1naphthol with concentrated hydrochloric acid at $100^{\circ} \mathrm{C}$ (waterbath) and extract it with dichloromethane. The extract was washed with $5 \%$ sodium carbonate, and then dried with sodium sulfate and potassium carbonate. Urinary 1-naphthol was determined as the pentafluorobenzylbromide derivative using gas chromatography (Hewlett Packard 5890) and electron capture detection, an autosampler, and an integrator (Hewlett Packard 3393). An NB-351 silica capillary column (HNU-Nordion Instruments Ltd, Finland, $25 \mathrm{~m}$, phase $0.2 \mathrm{~m}$, inner diameter $0.32 \mathrm{~mm}$ ) was used. The temperature was programmed as follows: $80^{\circ} \mathrm{C}$ (for $1 \mathrm{~min}$ ); rate of change $30^{\circ} \mathrm{C} / \mathrm{min}$ up to $210^{\circ} \mathrm{C}$ (for $30 \mathrm{~min}$ ). The carrier gas was helium $(1.5 \mathrm{ml} / \mathrm{min})$, and the detector make-up gas was argon-methane (95:5) (30 ml/min). Splitless injection was used.

All the standards and controls were made as replicates. Control urine was pooled urine, divided into approximately $5-\mathrm{ml}$ portions and kept frozen. The limit of detection was $0.07 \mathrm{~mol} / \mathrm{l}$, and the run-to-run variation 
was $7 \%$, as calculated from the control sample [25.1 (SD 3.0) $\mathrm{mol} / \mathrm{l}, \mathrm{N}=15]$. The within-run variation was $5 \%$ [30.1 (SD 1.6) $\mathrm{mol} / \mathrm{l}, \mathrm{N}=15]$. The recovery from the urine was 66.2 (SD 3.3)\%. The concentrations of 1naphthol in all the urine samples were normalized to a urine density of 1.024 .

\section{Results}

The average concentrations of naphthalene per workshift varied in the breathing zone air within a range of $0.4-$ $4.2 \mathrm{mg} / \mathrm{m}^{3}$. Naphthalene exposure by inhalation was highest for the assistant operators, on the average 2.2 3.0 (range $1.7-4.2) \mathrm{mg} / \mathrm{m}^{3}$, because they opened the impregnation cylinder manually and had to stay in the proximity of the cylinder. The end-of-shift levels of 1-naphthol were highest in the urine specimens of assistant operator 2 and tie plater 2 (table 1). The concentration of particulate PAH averaged $5.92 \mathrm{~g} / \mathrm{m}^{3}$ (range 1.2-13.7) during the workweek, and the proportion of $\mathrm{PAH}$ with 4 aromatic rings from total particulate $\mathrm{PAH}$ was $7 \%$. The main component of PAH containing 4 aromatic rings was pyrene, its concentration ranged from 0.23 to $2.20 \mathrm{~g} / \mathrm{m}^{3}$ (figure 1 ). The concentration of bentso[a]pyrene was from 0.01 to $0.05 \mathrm{~g} / \mathrm{m}^{3}$ in the breathing zone of the workers. Naphthalene and the particulate
PAH in air showed a poor correlation (table 2). The daily mean concentrations of naphthalene ranged from 0.9 to $2.2 \mathrm{mg} / \mathrm{m}^{3}$ during the workweek (table 3 ), the lowest air concentration was measured on Friday. The Monday, Wednesday, and Friday values for the end-of-shift mean for 1-naphthol ranged from 20.0 to $26.1 \mu \mathrm{mol} / 1$.

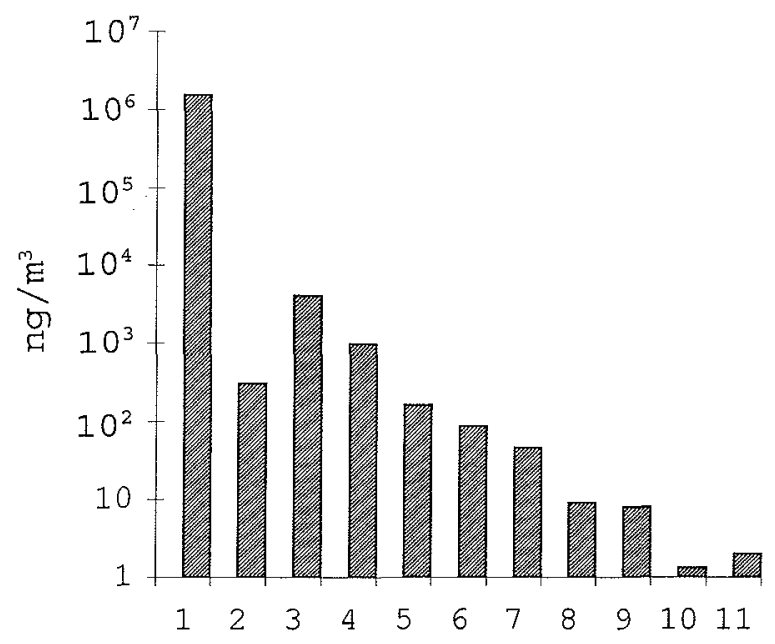

Figure 1. Mean concentrations of particulate polycyclic aromatic hydrocarbons (PAH) and vapors of naphthalene in the breathing zone of 6 workers in an impregnation plant during a workweek. $(1=$ naphthalene, 2 = fluorene, $3=$ phenanth, $4=$ pyrene, $5=$ chrysene, $6=\mathrm{B}(\mathrm{a})$ fluor, $7=\mathrm{B}(\mathrm{e})$ pyrene, $8=\mathrm{B}(\mathrm{k})$ fluoranth, $9=\mathrm{B}(\mathrm{a})$ pyrene, $10=\mathrm{B}($ ah) antracene, $11=\mathrm{B}($ chi)pyrene)

Table 1. Naphthalene and polycyclic aromatic hydrocarbon (PAH) concentrations in the breathing zone of workers during the work week, and 1-naphthol $\left(\mu \mathrm{g} / \mathrm{m}^{3}\right)$ in urine at the end of the shift.

\begin{tabular}{|c|c|c|c|c|c|c|c|c|}
\hline \multirow[t]{3}{*}{ Worker } & \multicolumn{2}{|c|}{ Naphthalene $\left(\mu \mathrm{g} / \mathrm{m}^{3}\right)$} & \multicolumn{4}{|c|}{$\mathrm{PAH}\left(\mu \mathrm{g} / \mathrm{m}^{3}\right)$} & \multicolumn{2}{|c|}{ 1-Naphthol $(\mu \mathrm{mol} / \mathrm{l})$} \\
\hline & \multirow[t]{2}{*}{ Mean } & \multirow[t]{2}{*}{ Range } & \multicolumn{2}{|c|}{ Total } & \multicolumn{2}{|c|}{$\geq 4$ rings } & \multirow[t]{2}{*}{ Mean } & \multirow[t]{2}{*}{ Range } \\
\hline & & & Mean & Range & Mean & Range & & \\
\hline $\begin{array}{l}\text { Operator } \\
\text { Assistant operator } 1 \\
\text { Assistant operator } 2 \\
\text { Truck driver } \\
\text { Tie plater } 1 \\
\text { Tie plater } 2\end{array}$ & $\begin{array}{r}560 \\
2220 \\
3020 \\
1070 \\
940 \\
1410\end{array}$ & $\begin{array}{c}370-790 \\
2510-3900 \\
1760-4200 \\
610-1600 \\
710-1500 \\
740-2500\end{array}$ & $\begin{array}{r}3.9 \\
7.2 \\
10.0 \\
6.7 \\
3.3 \\
4.5\end{array}$ & $\begin{array}{l}1.4-5.3 \\
2.8-11.0 \\
4.2-13.7 \\
3.4-8.6 \\
1.2-4.8 \\
1.6-8.6\end{array}$ & $\begin{array}{l}1.2 \\
1.5 \\
1.8 \\
2.0 \\
0.7 \\
0.9\end{array}$ & $\begin{array}{l}0.6-1.4 \\
0.8-2.3 \\
1.2-3.0 \\
1.1-3.3 \\
0.3-1.0 \\
0.5-1.3\end{array}$ & $\begin{array}{r}5.8 \\
26.5 \\
41.1 \\
9.8 \\
10.9 \\
30.3\end{array}$ & $\begin{array}{r}3.5-7.8 \\
17.3-35.7 \\
27.3-62.1 \\
6.7-14.8 \\
7.3-13.7 \\
20.3-39.3\end{array}$ \\
\hline Mean & 1540 & $370-4200$ & 5.9 & $1.2-13.7$ & 1.4 & $0.3-3.3$ & 20.5 & $3.5-62.1$ \\
\hline
\end{tabular}

Table 2. Correlation coefficients of the biological and air samples ( $\mathrm{PAH}=$ polycyclic aromatic hydrocarbons).

\begin{tabular}{|c|c|c|c|c|c|c|}
\hline & \multicolumn{2}{|c|}{ Air naphthalene } & \multicolumn{4}{|c|}{ Urinary 1-naphthol } \\
\hline & \multirow{2}{*}{$\begin{array}{l}\text { Correlation } \\
\text { coefficient }\end{array}$} & \multirow{2}{*}{$\begin{array}{c}\text { Number of } \\
\text { parallel } \\
\text { results }\end{array}$} & \multicolumn{2}{|c|}{ End of shift samples } & \multicolumn{2}{|c|}{ All samples } \\
\hline & & & $\begin{array}{l}\text { Correlation } \\
\text { coefficient }\end{array}$ & $\begin{array}{c}\text { Number } \\
\text { parallel } \\
\text { results }\end{array}$ & $\begin{array}{l}\text { Correlation } \\
\text { coefficient }\end{array}$ & $\begin{array}{c}\text { Number of } \\
\text { parallel } \\
\text { results }\end{array}$ \\
\hline Air naphthalene & . & . & 0.745 & 19 & . & . \\
\hline Air PAH & 0.413 & 30 & 0.575 & 19 & . & . \\
\hline Air PAH with $\geq 4$ rings & 0.397 & 30 & 0.189 & 19 & . & . \\
\hline Air pyrene & 0.407 & 30 & . & . & . & . \\
\hline Urinary 1-pyrenol end of shift & . & . & 0.458 & 17 & . & . \\
\hline All & . & . & . & . & 0.276 & 107 \\
\hline
\end{tabular}


Table 3. Urinary 1-naphthol levels of the creosote-exposed workers and the time-weighted average concentrations of naphthalene in air during a work week.

\begin{tabular}{|c|c|c|c|c|c|c|c|}
\hline & \multicolumn{4}{|c|}{ 1-Naphthol $(\mu \mathrm{mol} / \mathrm{l})$} & \multicolumn{3}{|c|}{ Naphthalene $\left(\mathrm{mg} / \mathrm{m}^{3}\right)$} \\
\hline & $\begin{array}{l}\text { Number } \\
\text { of } \\
\text { samples }\end{array}$ & Range & Mean & $\mathrm{SD}$ & $\begin{array}{l}\text { Number } \\
\text { of } \\
\text { samples }\end{array}$ & Mean & SD \\
\hline \multicolumn{8}{|l|}{ Monday } \\
\hline $\begin{array}{l}\text { Morning } \\
\text { At end of shift } \\
\text { Evening }\end{array}$ & $\begin{array}{l}5 \\
6 \\
5\end{array}$ & $\begin{array}{l}0.4-1.1 \\
6.2-35.7 \\
2.3-13.5\end{array}$ & $\begin{array}{r}0.7 \\
21.2 \\
7.1\end{array}$ & $\begin{array}{r}0.3 \\
11.9 \\
4.2\end{array}$ & 6 & 1.35 & 0.71 \\
\hline \multicolumn{8}{|l|}{ Tuesday } \\
\hline Morning & 6 & $1.0-6.9$ & 4.9 & 2.4 & 6 & 2.21 & 1.46 \\
\hline \multicolumn{8}{|l|}{ Wednesday } \\
\hline $\begin{array}{l}\text { Morning } \\
\text { At end of shift } \\
\text { Evening }\end{array}$ & $\begin{array}{l}6 \\
5 \\
6\end{array}$ & $\begin{array}{l}2.3-13.0 \\
7.8-62.1 \\
1.9-10.0\end{array}$ & $\begin{array}{r}6.5 \\
26.1 \\
5.5\end{array}$ & $\begin{array}{r}4.0 \\
24.0 \\
3.0\end{array}$ & 6 & 1.62 & 1.13 \\
\hline \multicolumn{8}{|l|}{ Thursday } \\
\hline Morning & 6 & $1.6-6.8$ & 3.9 & 2.3 & 6 & 1.58 & 0.98 \\
\hline \multicolumn{8}{|l|}{ Friday } \\
\hline $\begin{array}{l}\text { Morning } \\
\text { At end of shift } \\
\text { Evening }\end{array}$ & $\begin{array}{l}6 \\
6 \\
3\end{array}$ & $\begin{array}{l}0.5-5.3 \\
3.5-36.8 \\
0.8-14.7\end{array}$ & $\begin{array}{r}2.8 \\
20.0 \\
6.5\end{array}$ & $\begin{array}{r}1.8 \\
13.7 \\
6.9\end{array}$ & $\begin{array}{l}6 \\
.\end{array}$ & 0.94 & 0.57 \\
\hline \multicolumn{8}{|l|}{ Saturday } \\
\hline Morning & 5 & $1.0-36.8$ & 9.2 & 15.5 & & & \\
\hline After a 3-week holiday & 3 & $<0.1-0.3$ & 0.2 & . & . & . & . \\
\hline
\end{tabular}

For 3 workers, after a 3 -week holiday, the urinary 1 -naphthol ranged from less than 0.1 to $0.3 \mathrm{~mol} / \mathrm{l}$. The concentration of 1-naphthol in the urine of all 5 occupationally unexposed smoking referents was below the detection limit $(0.07 \mathrm{~mol} / \mathrm{l})$.

The results for urinary 1-naphthol are presented for 3 workers in figure 2. The lowest levels of 1-naphthol were found after the weekend on Monday morning, but the concentrations were, however, clearly higher than among the smoking referents. The highest concentrations were consistently found at the end of the shift. From all possible correlations, the time-weighted average concentration of naphthalene correlated best with the urinary 1-naphthol level measured at the end

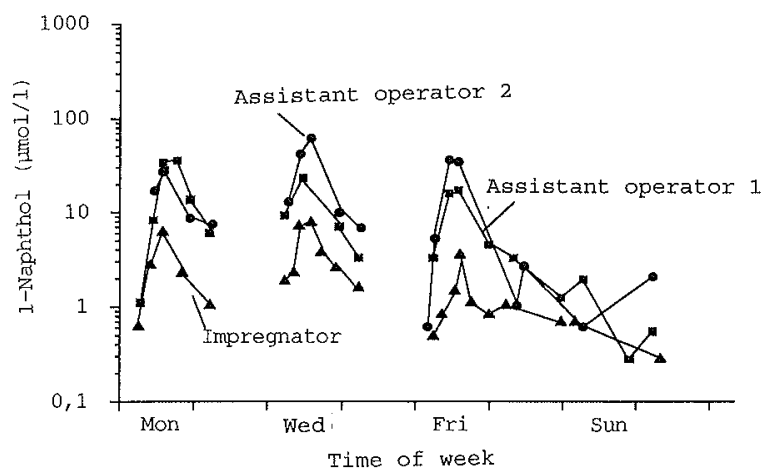

Figure 2. 1-Naphthol concentration in the urine of 3 workers in an impregnation plant during a workweek. of the shift (table 2, figure 3). The correlation between naphthalene in air and 1-naphthol in urine was lower when the urine concentrations were corrected for creatinine, as compared with correction for relative density.

All workers succeeded in collecting complete 24-h urine at least once during the week or the weekend. The total amount of excreted 1-naphthol was calculated (table 4). The inhalation uptake of naphthalene per workshift was estimated from an arbitrary lung ventilation of $25 \mathrm{l} / \mathrm{min}$ and $50 \%$ retention. The mean ratio of the 1-naphthol excretion (mol/24 h) over the respiratory uptake per workshift was 17 (SD 9)\% (table 4). The estimated daily uptake of naphthalene by inhalation corre-

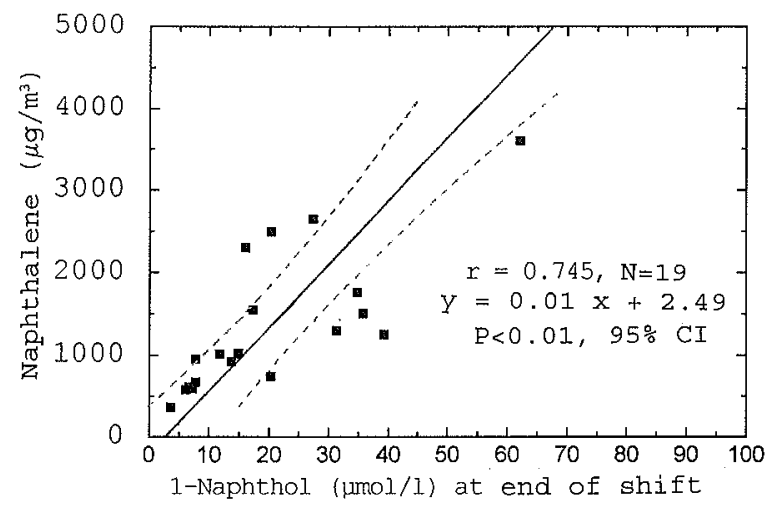

Figure 3. Correlation between naphthalene in breathing-zone air and 1 naphthol in urine at the end of a shift among 6 impregnation plant workers. 
Table 4. Excretion of 1 -naphthol/24 h and estimated inhalation uptake of naphthalene in an impregnation plant.

\begin{tabular}{|c|c|c|c|c|}
\hline Worker & $\begin{array}{l}\text { Number of } \\
\text { samples }\end{array}$ & $\begin{array}{l}\text { 1-Naphthol } \\
(\mu \mathrm{mol} / 24-h)\end{array}$ & $\begin{array}{c}\text { Inhaled } \\
\text { naphthalene } \\
\text { (umol/shift) }\end{array}$ & $\begin{array}{c}\text { Ratio } \\
\text { excreted:Inhaled }\end{array}$ \\
\hline \multicolumn{5}{|l|}{ Impregnator } \\
\hline $\begin{array}{l}\text { Monday } \\
\text { Wednesday } \\
\text { Friday }\end{array}$ & $\begin{array}{l}3 \\
3 \\
3\end{array}$ & $\begin{array}{l}3.2 \\
4.3 \\
1.4\end{array}$ & $\begin{array}{l}26 \\
32 \\
17\end{array}$ & $\begin{array}{l}0.13 \\
0.14 \\
0.08\end{array}$ \\
\hline Mean (SD) of the three days & 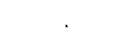 & $3.0(1.5)$ & $25.0(0.03)$ & $0.12(0.03)$ \\
\hline \multicolumn{5}{|l|}{ Assistant operator 1} \\
\hline $\begin{array}{l}\text { Monday } \\
\text { Wednesday } \\
\text { Friday }\end{array}$ & $\begin{array}{l}2 \\
2 \\
. .\end{array}$ & $\begin{array}{l}26.5^{b} \\
>3.63^{c} \\
8.4\end{array}$ & $\begin{array}{r}98 \\
103 \\
57\end{array}$ & $\begin{array}{l}0.27 \\
\ddot{0} \\
0.15\end{array}$ \\
\hline Mean of the three days & . & 17.5 & 77.5 & 0.21 \\
\hline \multicolumn{5}{|l|}{ Assistant operator 2} \\
\hline $\begin{array}{l}\text { Monday } \\
\text { Wednesday } \\
\text { Friday }\end{array}$ & $\begin{array}{l}2 \\
2 \\
2\end{array}$ & $\begin{aligned} & 6.3 \\
& 11.3 \\
&> 5.81^{\circ}\end{aligned}$ & $\begin{array}{r}102 \\
143 \\
60\end{array}$ & $\begin{array}{c}0.06 \\
0.08 \\
. .\end{array}$ \\
\hline Mean of the three days & . & 8.8 & 122.5 & 0.07 \\
\hline \multicolumn{5}{|l|}{ Truck driver } \\
\hline $\begin{array}{l}\text { Monday } \\
\text { Wednesday } \\
\text { Friday }\end{array}$ & $\begin{array}{l}2 \\
2 \\
2\end{array}$ & $\begin{array}{c}>3.9^{\mathrm{c}} \\
5.8 \\
9.1\end{array}$ & $\begin{array}{l}68 \\
38 \\
25\end{array}$ & $\begin{array}{l}\ddot{.} \\
0.15 \\
0.35\end{array}$ \\
\hline Mean of the three days & . & 7.5 & 31.5 & 0.25 \\
\hline \multicolumn{5}{|l|}{ Tie plater 1} \\
\hline $\begin{array}{l}\text { Monday } \\
\text { Wednesday } \\
\text { Friday }\end{array}$ & $\begin{array}{l}2 \\
2 \\
2\end{array}$ & $\begin{aligned} & 6.6 \\
& 9.3 \\
> & 2.3^{c}\end{aligned}$ & $\begin{array}{l}39 \\
37 \\
21\end{array}$ & $\begin{array}{l}0.17 \\
0.25 \\
.\end{array}$ \\
\hline Mean of the three days & & 7.9 & 3.8 & 0.21 \\
\hline \multicolumn{5}{|l|}{ Tie plater 2} \\
\hline $\begin{array}{l}\text { Monday } \\
\text { Wednesday } \\
\text { Friday }\end{array}$ & $\begin{array}{l}2 \\
2 \\
. .\end{array}$ & $\begin{array}{l}10.0 \\
11.6 \\
>5.1^{\circ}\end{array}$ & $\begin{array}{l}52 \\
50 \\
25\end{array}$ & $\begin{array}{l}0.19 \\
0.23 \\
. .\end{array}$ \\
\hline Mean of the three days & . & 10.8 & 51 & 0.21 \\
\hline $\begin{array}{l}\text { Mean (SD) of the } 3 \text { days } \\
\text { Monday } \\
\text { Wednesday } \\
\text { Friday }\end{array}$ & $\begin{array}{r}13 \\
13 \\
. .\end{array}$ & $\begin{array}{r}10.5(9.3) \\
8.5(3.3) \\
6.3(4.3)\end{array}$ & $\begin{array}{l}63.4(34.7) \\
60.0(46.9) \\
33.0(21.1)\end{array}$ & $\begin{array}{l}0.16(0.08) \\
0.17(0.07) \\
0.19(0.14)\end{array}$ \\
\hline Mean (SD) of the 3 days & . & $8.8(6.2)$ & $55.1(37.0)$ & $0.17(0.09)$ \\
\hline
\end{tabular}

a The inhalation uptake of naphthalene/workshift was calculated by estimating $25 \mathrm{l} / \mathrm{min}$ for lung ventilation and $50 \%$ retention.

- Overtime working from 1400 to 1800

- One voidance lost or partial, not included in mean values.

lated moderately with the 1-naphthol excretion over $24 \mathrm{~h}$ $(\mathrm{r}=0.534)$.

\section{Discussion}

The method of analysis for 1-naphthol applied in this study is sufficiently sensitive (detection limit $0.07 \mathrm{~mol} / \mathrm{l}$ ) for measuring even low occupational exposure to naphthalene. Engine exhaust (18) and tobacco smoke (19) contain some naphthalene. This background exposure results in undetectable urinary levels of 1-naphthol, however. 1-Naphthol may be analyzed also by high-pressure liquid chromatography, the detection limit of which is $0.04 \mu \mathrm{mol} / \mathrm{l}(20)$. Among nonoccupationally exposed persons, the 1-naphthol concentrations have been found to be $0.04-0.7 \mu \mathrm{mol} / 1$ (21) and $120 \mu \mathrm{g} / \mathrm{l}$, corresponding to $0.83 \mu \mathrm{mol} / 1$ (22). Only $3 \%$ of a large nonoccupationally exposed group has been shown to have 1-naphthol levels in excess of $10 \mathrm{ppb}$ (corresponding to $0.07 \mu \mathrm{mol} / \mathrm{l}$ ) (15). The variability of 1-naphthol levels among reference groups may be due to the different analytical methods used or to different background exposures.

Among our creosote workers the base-line concentrations of 1-naphthol in urine rose during the workweek and seemed to reach a steady state. The morning levels averaged from 4 to 13 times the Monday morning concentrations. After a 3-week holiday the urinary concentrations of 1-naphthol in 2 workers were still higher than among the referents. The urinary 1-naphthol level in the end-of-shift sample correlated rather well with naphthalene in the breathing-zone air. We made essentially the same observation previously with 3 workers assembling 
railroad switch elements (23). On 1 exceptional day, however, urinary 1-naphthol excretion was proportionally much higher than the estimated inhalation dose of naphthalene, the result suggesting dermal absorption. On the other hand there was no correlation between urinary 1-naphthol and the concentration of PAH and PAH with $\geq 4$ rings in air or 1-pyrenol in urine. This finding was not surprising since the poorly volatile $\mathrm{PAH}$, like pyrene, are taken up mainly through the skin (17). High 1-naphthol concentrations $(2.8-240 \mu \mathrm{mol} / \mathrm{l})$ have been detected in the urine of workers employed in the distillation of naphthalene oil and among coke oven workers (6.2$34.0 \mu \mathrm{mol} / 1$ ), and a linear dependence was found between the naphthalene in air and the urinary 1-naphthol of the coke plant workers (22).

$\mathrm{PAH}$ with 3 aromatic rings exhibited 2-10 times higher percutaneous fluxes than pyrene in a blood-perfused pig ear experiment, while PAH with 5-7 aromatic rings penetrated the skin $7-100$ times slower than pyrene (24). In an unpublished human study, $1.4-2 \%$ of the naphthalene dose of $0.5 \mathrm{mg} / \mathrm{kg}$ applied to the forearm skin $\left(25 \mathrm{~cm}^{2}\right)$ for $4 \mathrm{~h}$ could be found as 1-naphthol in urine within $24 \mathrm{~h}$ after the application (Luotamo et al, unpublished results). According to the same study, 5.6$8.4 \%$ of naphthalene taken up in the lungs $\left(0.8 \mathrm{mg} / \mathrm{m}^{3}\right.$, $4 \mathrm{~h}$ ) is excreted in urine as 1-naphthol. In rats, $4.6 \%$ of an oral naphthalene dose has been recovered as 1-naphthol or its glucuronide in urine (14). Assuming that a maximum of $10 \%$ of inhaled naphthalene is transformed to 1-naphthol and excreted in urine in a 24 -h period, one would expect to find about $5.5 \mu \mathrm{mol}$ of 1 -naphthol in urine over a $24-\mathrm{h}$ period, because the mean inhalation uptake was $55 \mathrm{~mol} /$ workday. In fact about $8.8 \mathrm{~mol}$ of 1-naphthol/24 h was found; this value allows some additional uptake of naphthalene through the skin or via ingestion. This conclusion on the absorption pathways for naphthalene contrasts with those for pyrene. It was found that the excretion of 1-pyrenol for the same persons varied from 0.3 to $1.5 \mathrm{~mol}$ per $24 \mathrm{~h}$ (17), while the estimated inhaled doses of vapors and particulate pyrene together amounted to only $0.03-0.09 \mathrm{~mol} /$ workshift. Hence the significance of skin absorption is much more important for pyrene than for naphthalene.

Naphthalene enters the body by inhalation, and it may also be taken up through the skin. Our observations indicate that occupational exposure to naphthalene can be assessed by measuring the 1-naphthol concentration in the urine at the end of the workshift. Naphthalene is the main component in creosote vapors; it constitutes $40-60 \%$ of the mass of the vapor phase in impregnation plants and $29-35 \%$ of the airborne substance when newly impregnated wood is being handled (6). By contrast, the air concentrations of 4-6 ring PAH have been $100-$ 200 times lower than that of naphthalene because of low volatility; during exposure these substances are mainly taken up through the skin. Therefore, urinary 1-naphthol alone is not a suitable marker substance either for the assessment of total PAH exposure or for the assessment of exposure to hydrocarbons with 5 or 6 fused aromatic rings, which are the major health concerns in relation to creosote because of carcinogenic properties.

\section{Acknowledgments}

The support of the Finnish State Railways, Railways Board, and the personnel at the impregnation plant are gratefully acknowledged.

We wish to thank Ms Mari Rothberg and Ms Tuula Karttunen for their skillful analytical assistance.

\section{References}

1. Wright $\mathrm{CW}$, Later DW, Wilson BW. Comparative chemical analysis of commercial creosotes and solvent refined coal-II materials by high resolution gas chromatography. J High Resolut Chromatogr Chromatogr Commun 1985;8:283-9.

2. Nylund L, Heikkilä $P$, Hämeilä $M$, Pyy L, Linnainmaa $K$ Sorsa M. Genotoxic effects and chemical compositions of four creosotes. Mutat Res 1992;265:223-36.

3. International Agency for Research on Cancer (IARC). Polyw nuclear aromatic compounds; part 4: bitumens, coal tars ad derived products, shale-oils and soots. Lyon: IARC, 1985. IARC monographs on the evaluation of the carcinogenic risk of chemicals to humans, vol 35 .

4. Karlehagen S, Andersen A, Ohlson C-G. Cancer incidence among creosote-exposed workers. Scand J Work Environ Health 1992;18(1):26-9.

5. Schoket B, Hewer A, Grover PL, Phillips DH. Covalent binding of components of coal-tar, creosote and bitumen to the DNA of the skin and lungs of mice following topical application. Carcinogenesis 1988;9:1253-8.

6. Heikkilä PR, Hämeilä M, Pyy L, Raunu P. Exposure to creosote in the impregnation and handling of impregnated wood. Scand J Work Environ Health 1987;13:431-7.

7. National Institute for Occupational Safety and Health. Two petroleum refinery worker's exposure to PAHs at fluid catalytic cracker, coker, and asphalt processing units. Cincinnati $(\mathrm{OH})$ : National Institute for Occupational Safety and Health, 1983. DHHS 2 Pub No $83-111$.

8. Hicks JB. Asphalt industry cross-sectional exposure assessment study. Appl Occup Environ Hyg 1995;10:840-8.

9. Buchet JP, Gennart JP, Mercado-Calderon F, Delavignette JP, Cupers L, Lauwerys R. Evaluation of exposure to polycyclic aromatic hydrocarbons in a coke production and a graphite electrode manufacturing plant: assessment of urinary excretion of 1-hydroxypyrene as a biological indicator of exposure. Br J Ind Med 1992;49:761-8.

10. Purdham JT, Bozek PR, Sass-Kortsak A. The evaluation of exposure of printing trade employees to polycyclic aromatic hydrocarbons. Ann Occup Hyg 1993;37(1):35—44.

11. Vainitalo $S$, Matveinen $\mathrm{K}$. Cooking fumes as a hygienic problem in the food and catering industries. Am Ind Hyg Assoc 1993;54:193-82. 
12. Jerina M, Daly JW, Witkop P, Zaltzman-Nirenberg P, Udebfried S. 1,2-Naphthalene oxide as an intermediate in the microsomal hydroxylation of naphthalene. Biochemistry 1970;9: $147-56$.

13. Horning MG, Stillwell WG, Griffin GW, Tsang W-S. Epoxide intermediates in the metabolism of naphthalene by the rat. Drug Metab Disposition, 1980;8:404-14.

14. Bakke J, Struble C, Gustafsson JÅ, Gustafsson B. Catabolism of premercapturic acid pathway metabolites of naphthalene to naphthols and methylthio-containing metabolites in rats. Proc Natl Acad Sci USA 1985;82:668-71.

15. Keimig SD, Morgan DP. Urinary 1-naphthol as a biological indicator of naphthalene exposure. Appl Ind Hyg 1986;1(2): $61-5$.

16. Tingle MD, Pirmohamed M, Templeton E, Wilson AS, Madden, S, Hitteringdram NR, et al. An investigation of the formation of cytotoxic, protein-reactive and stable metabolites from naphthalene by human liver microsomes. Biochem Pharmacol 1993:46:1529-38.

17. Elovaara E, Heikkilä P, Pyy L, Mutanen P, Riihimäki V. Significance of dermal and respiratory uptake in creosote workers: exposure to polycyclic aromatic hydrocarbons and urinary excretion of 1-hydroxypyrene. Occup Environ Med 1995;52.

18. International Agency for Research on Cancer (IARC). Diesel and gasoline engine exhausts and some nitroarenes. Lyon: IARC, 1989. IARC monographs on the evaluation of the car- cinogenic risk of chemicals to humans, vol 46 .

19. Schmeltz I, Tosk J, Hoffman D. Formation and determination of naphthalenes in cigarette smoke. Anal Chem 1976;48(4): 645-50.

20. Hansen $\AA$ M, Poulsen OM, Christensen JM, Hansen ST. Determination of $\alpha$-naphthol in human urine by high performance liquid chromatography. J Liq Chromatograph 1992;15 479-99.

21. Hansen ÅM, Omland Ö, Poulsen OM, Sherson D, Sigsgaard $\mathrm{T}$, Christensen JM, et al. Correlation between work processrelated exposure to polycyclic aromatic hydrocarbons and urinary levels of alpha-naphthol, beta-naphthylamine and 1-hydroxypyrene in iron foundry workers. Int Arch Occup Environ Health 1994;65:385-94.

22. Bieniek $\mathrm{Gr}$. The presence of 1-naphthol in the urine of industrial workers exposed to naphthalene. Occup Environ Med 1994:51:357-9.

23. Heikkilä $\mathrm{P}$, Luotamo $\mathrm{M}$, Riihimäki V. Urinary 1-naphthol and 1-pyrenol as indicators of exposure to coal tar products. Int Arch Occup Environ Health 1995;67:211-7.

24. Van Rooij JGM, Vinke E, DeLange J, Bruijnzeel PLB, Bodelier-Bade MM, Noordhoek J, et al. Dermal absorption of polycyclic aromatic hydrocarbons in the blood-perfused pig ear. J Appl Toxicol 1995;15(3):193-200.

Received for publication: 20 November 1996 